\title{
Forty years of epikarst: what biology have we learned?
}

\author{
Tanja Pipan ${ }^{1}$ and David C. Culver ${ }^{2 *}$ \\ ${ }^{1}$ Karst Research Institute at ZRC SAZU, Titov trg 2, SI-6230 Postojna, Slovenia \\ ${ }^{2}$ Department of Environmental Science, American University, 4400 Massachusetts Ave. NW, Washington DC, U.S.A.
}

\begin{abstract}
Epikarst is not only an important component of the hydrogeology of karst and an active site of speleogenesis, it is habitat for a number of species adapted to subterranean life. Water in epikarst, with a residence time of days to months, is a highly heterogeneous habitat, and the animals are primarily sampled from continuously sampling dripping water or collecting from residual drip pools. While the subterranean fauna of cracks and crevices has been known for over 100 years, it is only in the past several decades that epikarst has been recognized as a distinct habitat, with reproducing populations of stygobionts. Dissolved organic carbon in epikarst drip water is a primary and sometimes the only source of organic matter for underlying caves, especially if there are not sinking streams that enter the cave. Typical concentrations of organic carbon are $1 \mathrm{mg} \mathrm{L}^{-1}$. The fauna of epikarst is dominated by copepods, but other groups, including some terrestrial taxa, are important in some areas. Most of the diversity is $\beta$-diversity (between drips and between caves). In Slovenia, an average of nearly 9 stygobiotic copepod species were found per cave. In studies in Romania and Slovenia, a number of factors have been found to be important in determining species distribution, including ceiling thickness, habitat connectivity and habitat size. In addition to eye and pigment loss, epikarst copepod species may show a number of specializations for life in epikarst, including adaptations to avoid displacement by water flow. Several geoscientists and biologists have challenged the uniqueness and importance of epikarst, but on balance the concept is valid and useful. Fruitful future research directions include development of better sampling techniques, studies to explain differences among nearby epikarst communities, phylogeographic studies, and assessing the possible role of copepods as tracers of vadose water.
\end{abstract}

Keywords: $\quad$ adaptation; cave ecology; Copepoda; stygobionts; subterranean biodiversity

Received 21 March 2013; Revised 7 July 2013; Accepted 15 July 2013

Citation: $\quad$ Pipan T. and Culver D.C., 2013. Forty years of epikarst: what biology have we learned? International Journal of Speleology, 42 (3), 215-223. Tampa, FL (USA) ISSN 0392-6672 http://dx.doi.org/10.5038/1827-806X.42.3.5

\section{INTRODUCTION}

Forty years ago, in 1973, Mangin coined the phrase "epikarst" for the uppermost layer of karst, an active zone of transfer between karst and the overlying soil. Since that time, epikarst has become recognized as an important zone of water storage, of speleogenesis, and an important biological habitat (Pipan, 2005; Williams, 1983). It was the subject of an interdisciplinary symposium organized by the Karst Waters Institute (Jones et al., 2004), and a review by Williams in this journal in 2008 provided a hydrogeological perspective on epikarst. In this review we propose to provide a biological perspective on epikarst, the fortieth anniversary of the coining of the term epikarst being an appropriate marker.

We begin with an overview of the physical and chemical aspects of the habitat, summarize what is known of the biology of epikarst, evaluate challenges, both biological and hydrogeological, that have be posed to the importance of epikarst, and conclude with some suggestions for future research.

\section{The epikarst habitat}

Wherever there is soil covering base rock, there is a zone of contact between the rock and the soil, typically consisting of an unconsolidated layer of rock mixed with soil-the regolith. This zone often has spaces larger than the soil above. When the base rock is water soluble at the $\mathrm{pH}$ of water in the area, these spaces are greatly enhanced by the dissolution of rock into small channels and cavities. It is the shallow part of karst areas, where stress release, climate, tree roots, and karst processes fracture and enlarge rock joints and cracks, creating a more permeable and porous zone over the carbonate rock in which only a few vertical joints and cracks occur (Bakalowicz, 2012). 
The word epikarst came into widespread use in the 1990s following the definition by Mangin (1973) of an epikarst aquifer as a perched saturated zone within the superficial part of the karst that stores a part of the infiltrated water (Bakalowicz, 2012). Typically 3 to $10 \mathrm{~m}$ thick, epikarst overlies the water infiltration zone. Participants in a workshop on epikarst (Jones et al., 2004) decided upon the following definition of epikarst:

Epikarst is located within the vadose zone and is defined as the heterogeneous interface between unconsolidated material, including soil, regolith, sediment, and vegetative debris, and solutionally altered carbonate rock that is partially saturated with water and capable of delaying or storing and locally rerouting vertical infiltration to the deeper, regional, phreatic zone of the underlying karst aquifer.

According to Williams (2008), the typical porosity (per cent open space) of unweathered limestone is 2 percent while that of epikarst typically exceeds 20 percent. More generally, water storage in epikarst is the reason why cave streams typically have water for long periods of drought.

What we know about epikarst mostly comes from the study of the outflow of dripping water in caves. This outflow has a complex connection with precipitation (Kogovšek, 2010), and also includes water from other parts of the vadose zone. Typically, output spikes after several precipitation events, which cumulatively fill the cavities in epikarst, but different cavities fill at different rates. Based on continuous monitoring of three drips for three years in Postojnska jama (Slovenia), Kogovšek was able to estimate total surface catchment area of an individual drip using precipitation and drip rate data (Table 1). Even the largest catchment area of a drip (I in Table 1) was quite small, approximately $200 \mathrm{~m}^{2}$. These catchment areas are to a certain extent virtual since the actual connections between drips and the surface are complex and likely to be overlapping.

Bottrell and Atkinson (1992) found by direct observation of water soluble dye in White Scar Cave, England, that there were three flow components:

1. A rapid through-flow with a residence time of 3 days

2. A short-term storage of 30 to 70 days, and

3. A long-residence time of 160 days or more, water flushed out only during periods of high flow.

Table 1. Yearly volume of outflow, in $\mathrm{m}^{3}$, through three drips (I, J, and $\mathrm{L}$ ) in Postojnska jama, with calculated catchment area, in $\mathrm{m}^{2}$, defined by dividing outflow by annual precipitation for that year. Data from Kogovšek (2010).

\begin{tabular}{|l|c|c|c|c|c|c|}
\hline & \multicolumn{2}{|c|}{2003} & \multicolumn{2}{c|}{2004} & \multicolumn{2}{c|}{2005} \\
\hline Drip & $\mathrm{m}^{3}$ & $\mathrm{~m}^{2}$ & $\mathrm{~m}^{3}$ & $\mathrm{~m}^{2}$ & $\mathrm{~m}^{3}$ & $\mathrm{~m}^{2}$ \\
\hline $\mathrm{I}$ & 299 & 244.8 & 175 & 158.5 & 216 & 204.9 \\
\hline $\mathrm{J}$ & 12.2 & 10.0 & 7.3 & 7.3 & 10.4 & 9.9 \\
\hline $\mathrm{L}$ & 0.16 & 0.1 & 0.06 & 0.1 & 0.186 & 0.2 \\
\hline TOTAL & 311.4 & 255 & 182.2 & 165 & 226.6 & 215 \\
\hline
\end{tabular}

Clearly, the extent of the long residence time interval depends on rainfall variation. Kogovšek (2010) calculated overall residence times in two drips in Postojnska jama, based on oxygen isotope composition (Kogovšek \& Urbanc, 2007) of 2.5 months to over a year.

Epikarst is also an important site of dissolution of $\mathrm{CaCO}_{3}$. Ford and Williams (2007) point out that about 70 percent of the dissolution takes place in the top $10 \mathrm{~m}$ of limestone, the typical extent of epikarst. Epikarst acts as a reservoir for the accumulation of organic matter coming from the soil (Bakalowicz, 2012). Organic carbon has a dual role in epikarst, as a source of food for heterotrophic organisms in epikarst and as source of $\mathrm{CO}_{2}$ and ultimately $\mathrm{H}_{2} \mathrm{CO}_{3}$ (carbonic acid) in carbonate dissolution. Epikarst thus acts as a $\mathrm{CO}_{2}$ reservoir, recharging the infiltration zone as water moves vertically downward. Consequently, storage of $\mathrm{CO}_{2}$ in epikarst is an essential mechanism for karst development at the surface as well as at depth (Bakalowicz, 2012).

Pipan (2003, 2005) provided extensive data on inorganic chemistry of drips in her study of the epikarst fauna of six Slovenian caves, summarized in Table 2. As expected, conductivity was high, largely because of the high concentration of $\mathrm{Ca}^{2+}$ ions. Meleg et al. (2011b) did a similar analysis for three Romanian caves for $\mathrm{pH}$, conductivity, and $\mathrm{NO}_{2}^{-}$as well as the concentrations of several heavy metals$\mathrm{Al}^{3+}, \mathrm{Cr}^{3+}$, and $\mathrm{Fe}^{3+}$ (Table 3). Compared to Slovenian caves (Table 2), $\mathrm{pH}$ was consistently higher in the Romanian caves, above 8.0; conductivity, except in Peştera Vadu Crişului, was lower and nitrites were much higher in Romanian caves than in Slovenian caves. Differences in parent rock and anthropogenic impacts are likely the reasons for the discrepancy between the two countries.

Two consistent themes emerge from the studies of geochemistry of dripping water. One is that drip water has high concentrations of the ions associated with $\mathrm{CaCO}_{3}$ dissolution, e.g., $\mathrm{Ca}^{2+}$, the result of water being in contact with carbonate rock for significant periods of time, i.e., weeks to months. The second theme is that there is considerable temporal and spatial variability in geochemistry, even at scales on the order of 10 meters.

Organic carbon in drip water is especially interesting because the fauna of epikarst and caves is likely carbon- rather than nutrient- (nitrogen or phosphorus) limited (Simon \& Benfield, 2002; Simon et al., 2007). The source of organic carbon in epikarst water is the soil. Rainwater does not contain organic carbon, but because of biological activity in the soil, water leaching from the soil into epikarst cavities has organic carbon.

Simon et al. (2007) measured dissolved organic carbon (DOC) concentrations in both Organ Cave, West Virginia, U.S.A. and Postojna Planina Cave System (PPCS) in Slovenia, as did Ban et al. (2008) in Shihua Cave, China. In Organ Cave, mean DOC concentrations in the unsaturated zone were 1.10 $\mathrm{mg} / \mathrm{L}$ while in PPCS they were $0.70 \mathrm{mg} / \mathrm{L}$ (Table 4). The differences are likely the result of different land uses. The land above Organ Cave is mostly pasture and the land above PPCS is forest. In addition to water entering 
Table 2. Average values and coefficients of variation (standard deviation X 100/mean) for $\mathrm{pH}$, conductivity, and nine ions for six Slovenian caves. Ionic concentrations are in $\mathrm{mg} / \mathrm{L}$. Data from Pipan $(2003,2005)$.

\begin{tabular}{|c|c|c|c|c|c|c|c|c|c|c|c|c|}
\hline Cave & & $\mathrm{pH}$ & $\begin{array}{c}\text { Conductivity } \\
(\mu \mathrm{S} / \mathrm{cm})\end{array}$ & $\mathrm{NH}_{4}^{+}$ & $\mathrm{K}^{+}$ & $\mathrm{Ca}^{2+}$ & $\mathrm{Na}^{+}$ & $\mathrm{Mg}^{2+}$ & $\mathrm{NO}_{3}^{-}$ & $\mathrm{NO}_{2}^{-}$ & $\mathrm{SO}_{4}{ }^{2-}$ & $\mathrm{Cl}^{-}$ \\
\hline \multirow[t]{3}{*}{ Črna jama } & Mean & 7.84 & 376.67 & 0.08 & 0.39 & 36.64 & 0.94 & 0.71 & 0.64 & 0.004 & 4.91 & 1.14 \\
\hline & Coeff. Var. & 2.55 & 22.89 & 34.43 & 37.91 & 68.13 & 222.43 & 69.36 & 150.80 & 236.52 & 59.78 & 62.51 \\
\hline & $\mathrm{n}$ & 70 & 70 & 25 & 25 & 25 & 25 & 25 & 25 & 25 & 25 & 25 \\
\hline \multirow{3}{*}{ Dimnice } & Mean & 7.70 & 330.04 & 0.11 & 0.42 & 36.86 & 2.16 & 0.95 & 3.16 & 0.001 & 5.17 & 5.54 \\
\hline & Coeff. Var. & 2.55 & 25.94 & 74.83 & 52.18 & 40.42 & 91.25 & 63.14 & 190.16 & 345.22 & 80.84 & 135.08 \\
\hline & $\mathrm{n}$ & 45 & 45 & 45 & 45 & 45 & 45 & 45 & 45 & 45 & 45 & 45 \\
\hline \multirow[t]{3}{*}{ Pivka jama } & Mean & 7.84 & 416.36 & 0.11 & 0.83 & 42.93 & 2.17 & 1.14 & 11.81 & 0.012 & 5.44 & 2.37 \\
\hline & Coeff. Var. & 3.39 & 27.73 & 69.95 & 50.41 & 61.69 & 94.82 & 60.56 & 122.62 & 399.73 & 46.81 & 69.84 \\
\hline & $\mathrm{n}$ & 69 & 69 & 24 & 24 & 24 & 24 & 24 & 24 & 24 & 24 & 24 \\
\hline \multirow{3}{*}{$\begin{array}{l}\text { Postojnska } \\
\text { jama }\end{array}$} & Mean & 7.81 & 342.57 & 0.07 & 0.42 & 39.00 & 0.99 & 0.86 & 3.09 & 0.001 & 5.73 & 1.26 \\
\hline & Coeff. Var. & 2.38 & 27.28 & 52.63 & 32.31 & 36.42 & 42.80 & 31.25 & 74.57 & 433.17 & 47.79 & 36 \\
\hline & $\mathrm{n}$ & 219 & 219 & 69 & 69 & 69 & 69 & 69 & 69 & 69 & 69 & 69 \\
\hline \multirow{3}{*}{$\begin{array}{l}\text { Škocjanske } \\
\text { jame }\end{array}$} & Mean & 7.87 & 308.40 & 0.12 & 0.45 & 23.64 & 1.40 & 0.88 & 1.05 & 0.004 & 6.40 & 0.37 \\
\hline & Coeff. Var. & 2.14 & 28.43 & 104.46 & 53.11 & 68.55 & 77.70 & 52.56 & 95.29 & 655.74 & 43.66 & 54.9 \\
\hline & $\mathrm{n}$ & 43 & 43 & 43 & 43 & 43 & 43 & 43 & 43 & 43 & 43 & 43 \\
\hline \multirow{3}{*}{$\begin{array}{l}\text { Županova } \\
\text { jama }\end{array}$} & Mean & 7.65 & 371.29 & 0.10 & 0.46 & 47.83 & 0.88 & 1.09 & 0.31 & 0.001 & 8.74 & 1.4 \\
\hline & Coeff. Var. & 3.09 & 20.89 & 44.75 & 45.85 & 30.05 & 68.72 & 17.10 & 47.64 & 343.60 & 21.26 & 46.69 \\
\hline & $n$ & 45 & 45 & 45 & 45 & 45 & 45 & 45 & 45 & 45 & 45 & 45 \\
\hline
\end{tabular}

cave passages through percolating water, both caves had sinking streams (Fig. 1). DOC concentrations in sinking streams averaged at least five times higher than in percolating water (Table 4). However, many conduits in both caves had no stream, and the only source of carbon was percolating water. The total amount of DOC in cave streams depended in large part on the relative contribution of sinking streams and epikarst drips. In PPCS, the sinking stream was much larger than in Organ Cave, and DOC concentrations were accordingly higher (Table 4).

An equally interesting question is the type, or quality, of organic carbon in epikarst. The source of organic carbon in the epikarst ultimately comes from the decomposition of material at or near the soil surface, e.g., leaf litter, and in the soil, especially from the result of extra-cellular enzymes secreted by the microbial community.

Table 3. Average values and coefficients of variation (standard deviation $\mathrm{X}$ $100 /$ mean) for $\mathrm{pH}$, conductivity, $\mathrm{NO}_{2}^{-}, \mathrm{Al}^{3+}, \mathrm{Cr}^{3+}$, and $\mathrm{Fe}^{3+}$ in three caves in Romania. lonic concentrations are in mg/L. Data from Meleg et al. (2011b).

\begin{tabular}{|l|c|c|c|c|c|c|c|}
\hline \multirow{2}{*}{ Cave } & & $\mathbf{p H}$ & $\begin{array}{c}\text { Conductivity } \\
(\boldsymbol{\mu} \mathbf{S} / \mathbf{c m})\end{array}$ & $\mathbf{A})^{3+}$ & $\mathbf{C r}^{3+}$ & $\mathbf{F e}^{3+}$ & $\mathbf{N O}_{2}$ \\
\hline $\begin{array}{l}\text { Peştera } \\
\text { Ungurului }\end{array}$ & Mean & 8.70 & 256.13 & 0.42 & 0.01 & 0.63 & 0.25 \\
\cline { 2 - 8 } & $\begin{array}{c}\text { Coeff. } \\
\text { Var. }\end{array}$ & 4.02 & 28.88 & 169.05 & 200.00 & 115.87 & 96.00 \\
\cline { 2 - 8 } & $\mathrm{n}$ & 12 & 12 & 12 & 12 & 12 & 12 \\
\hline $\begin{array}{l}\text { Peştera } \\
\text { Vadu } \\
\text { Crişului }\end{array}$ & \begin{tabular}{c} 
Mean \\
\cline { 2 - 8 }
\end{tabular} & 8.36 & 380.84 & 0.11 & 0.01 & 0.31 & 0.46 \\
\cline { 2 - 8 } & $\begin{array}{c}\text { Coeff. } \\
\text { Var. }\end{array}$ & 2.75 & 15.88 & 63.64 & 100.00 & 203.23 & 76.09 \\
\hline \multirow{2}{*}{$\begin{array}{l}\text { Peştera } \\
\text { Ciur Izbuc }\end{array}$} & Mean & 8.49 & 265.31 & 0.54 & 0.01 & 2.94 & 0.44 \\
\cline { 2 - 8 } & $\begin{array}{c}\text { Coeff. } \\
\text { Var. }\end{array}$ & 2.59 & 32.24 & 135.19 & 200.00 & 211.22 & 261.36 \\
\cline { 2 - 8 } & $\mathrm{n}$ & 12 & 12 & 12 & 12 & 12 & 12 \\
\hline
\end{tabular}

Table 4. Estimates of dissolved organic carbon in $\mathrm{mg} / \mathrm{L}$ from Organ Cave, West Virginia (USA) and Postojna Planina Cave System (Slovenia). From Simon et al. (2007). Used with permission of the National Speleological Society (www.caves.org).

\begin{tabular}{|l|c|c|}
\hline & Organ Cave & $\begin{array}{c}\text { Postojna Planina } \\
\text { Cave System }\end{array}$ \\
\hline Input: sinking streams & $7.67 \pm 1.03$ & $4.36 \pm 0.46$ \\
\hline Input: percolation water & $1.10 \pm 0.15$ & $0.70 \pm 0.04$ \\
\hline In cave: streams & $1.08 \pm 0.32$ & $4.75 \pm 1.57$ \\
\hline Output: resurgence & $0.90 \pm 0.17$ & $2.67 \pm 0.80$ \\
\hline
\end{tabular}

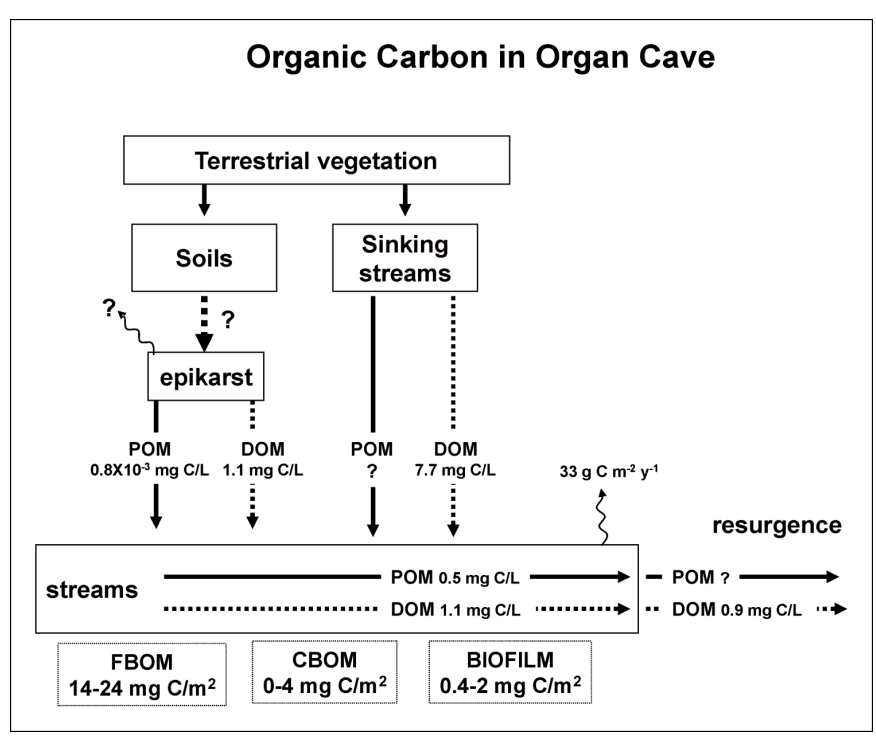

Fig. 1. A conceptual model of energy flow and distribution (as organic carbon) in a karst basin with estimates of fluxes and standing crops for Organ Cave, West Virginia, USA. Standing stocks are particulate (POM) and dissolved (DOM) organic matter in the water column and fine (FBOM) and coarse (CBOM) benthic organic carbon and microbial films on rocks (epilithon). Solid and dashed arrows represent fluxes. Data are standing stocks of carbon except for respiration flux, shown by the wavy arrow. Values for FBOM, CBOM and microbial film are taken from Simon et al. (2003), the whole-stream respiration rate (wavy arrow) is from Simon and Benfield (2002); and the remaining values are from Simon et al. (2007). Modified from Simon et al. (2007). Used with permission of the National Speleological Society (www.caves.org). 
Simon et al. (2010) measured specific UV absorbance (SUVA) at $254 \mathrm{~nm}$, a standard measure of the frequency of aromatic compounds (McKnight et al., 2001), for Organ Cave and Postojna Planina Cave System (PPCS). Higher SUVA values tend to mean the compounds are less reactive and less easy to metabolize but there are numerous caveats (Weishaar et al., 2003). The pattern, which is very similar for both caves, is shown in Fig. 2. Soil, one of the sources of DOC in epikarst, had relatively high SUVA and percolating water drips had relatively low SUVA. SUVA values suggest that the organic carbon in epikarst is more metabolically accessible than that of the soil, or at least with lower percentages of aromatic and humic compounds.

\section{History of biological studies of epikarst}

Beginning with Racoviță's 1907 classic "Essai sur les problèmes biospéologiques", biologists have recognized that much of the fauna observed in cave passages accessible by humans often occurs more frequently in cracks and crevices. In Racoviță's time, the epikarst zone was completely unknown to hydrogeologists, and he can scarcely be faulted for not identifying it as a separate habitat. By the mid $20^{\text {th }}$ century, several biologists, such as Petkovski (1959), became aware that there were stygobiotic copepods in caves with no streams and only percolating water. He recognized that the accumulation of water from above depended on fractured rock, and that there was water in tiny fissures and cracks which slowly flowed down from the ceiling. He believed that this habitat was the realm of copepods like Speocyclops as well as many harpacticoids. Thus he didn't recognize the infiltration zone as a habitat per se, but as a source of water that filled small depressions in walls, the "realm of Parastenocarida". Holsinger (1971) came to similar view with respect to a population of the amphipod Crangonyx antennatus living in Molly Waggle Cave in Virginia. Part of the population was in an old trough used for saltpetre mining during the American Civil War. He concluded that the only way the individuals could have gotten there was via what we would now call epikarst, but he reviewed it more as a dispersal corridor than a habitat.

In his study of copepods in the Baget karst basin in France, Rouch (1968, pers. comm.) recognized that the small number of individuals occurring in pools

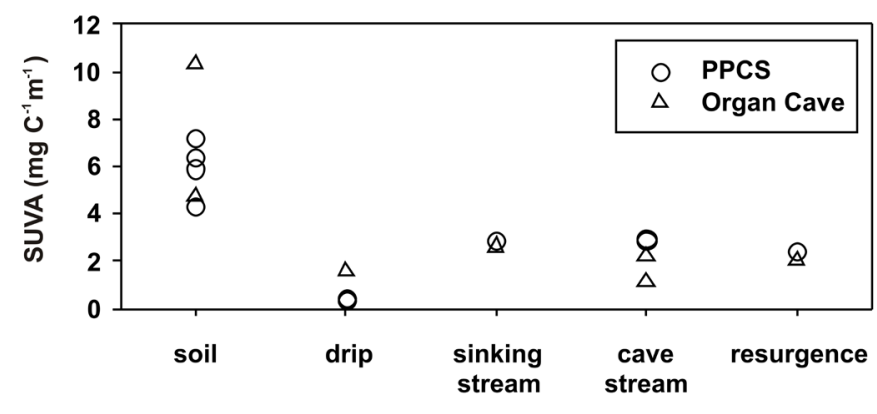

Fig. 2. Specific UV absorbance (SUVA) for DOC samples from soil extracts, epikarst drips, sinking streams, cave streams, and resurgences at PPCS and Organ Cave karst aquifers in September 2007. From Simon et al. (2010). in Grotte de Sainte-Catherine was much too small to constitute a viable population and concluded that there were populations in perched, i.e., epikarst, aquifers. Rouch had the advantage of collaborating with Mangin (1973), one of the discoverers of epikarst. Other French biologists, notably Delay (1968) and Gibert (1986) studied the fauna of percolating waters, and included terrestrial species in their study, but did not distinguish different components of the zone of percolation.

Brancelj's (2002) discovery of a rich copepod fauna in drip pools in the shallow Slovenian cave Velika Pasica, which has no other water, but with relatively few reproducing individuals, led him to conclude that reproduction was occurring in "small cracks around the cave". Although he did not use the phrase epikarst, the cave is so shallow that most of the ceiling is epikarst. Unlike Petkovski and Holsinger, he held that reproduction was not occurring in the cave but in crevices in the cave ceiling and walls. Pipan (2003, 2005) championed the idea that there was an epikarst habitat and fauna distinct from other subterranean habitats, and developed innovative techniques to sample dripping water continuously (Pipan \& Brancelj, 2001). Camacho et al. (2006) extensively sampled epikarst pools (but not the drips directly) and found a large number of stygobiotic species in Ojo Guareña cave in Spain. Culver and Pipan (2011) argued that epikarst was one of several aquatic shallow subterranean habitats each of which harbors a unique, troglomorphic, stygobiotic fauna.

Moldovan, and her colleagues initiated an intensive study of Romanian caves in the mid 2000's, emphasizing community structure and diversity (Meleg et al., 2011a, 2011b), as well as effects of habitat fragmentation and quality (Moldovan et al., 2011). During the same time period, Simon and colleagues (2007, 2010) integrated epikarst into models of organic carbon flux in caves, and provided the first measurements of dissolved organic carbon.

\section{Overview of the epikarst fauna}

The epikarst fauna, best collected directly from dripping water rather than pools (see below), is typically dominated by copepods (Pipan, 2005; Pipan \& Culver, 2005; Meleg et al., 2011b). Other groups may be present in considerable numbers, including amphipods, ostracods, and even syncarids, depending on the location. Terrestrial species are also sometimes common in dripping water, presumably having been flushed out of their air-filled cavity. Nonetheless, the bulk of biological studies have emphasized the copepod fauna.

Not all species found in epikarst are epikarst endemics, or even stygobionts (aquatic species limited to subterranean waters). For the 35 drips in six caves studied by Pipan (2005), the number of (1) epikarst endemic copepod species, (2) nonepikarst endemic stygobiont copepod species, and (3) non-stygobiont copepod species was about the same, ranging between 10 and 15 (Fig. 3). For all Slovenian records, non-epikarst endemic stygobionts and non-stygobiont species were approximately equal in number, while the number of epikarst endemics was approximately half of the other two categories. 
The reduced relative frequency of epikarst endemic species is not surprising since only seven caves have been thoroughly investigated.

It is interesting to consider the relative abundance of the different categories of species-epikarst endemic, non-epikarst endemic stygobiont, and non-stygobiont, because one could hypothesize that the three categories represent different stages of adaptation, with non-stygobionts being the least adapted. For the six caves where drips were sampled directly (Pipan, 2003, 2005), it is possible to test this directly. Using overall abundance of each species in drip samples as the variable, the mean abundance of non-stygobionts was the lowest of the three groups, as expected (Table 5), but the presumably specialized epikarst endemics were less than half as abundant as the other stygobionts. Overall however, the ANOVA was not significant $(\mathrm{p}=0.0516$, Table 5), indicating no significant differences in abundance among the ecological groups.

\section{Copepod species diversity and richness in epikarst}

Malard et al. (2009) analyzed data on stygobiotic groundwater species on a European wide scale and found that local a-diversity (in their case a local aquifer) contributed less than ten percent to overall species richness, and suggested that among sites $\beta$-diversity was characteristically high in subterranean systems. Sampling data on epikarst drips allows for the analysis of even finer spatial scales. The same pattern of low a-diversity and high $\beta$-diversity demonstrated by Malard et al. (2009) for the stygofauna as a whole on a European wide scale was found for epikarst copepods for smaller geographic scales-ranging from individual drips to the south central region of Slovenia (Pipan \& Culver, 2007a). The three components of total epikarst copepod diversity were partitioned as follows:

- 12 percent (3.20 species) of the total species richness was within-drip diversity (a-diversity)

- 20 percent (5.47 species) of the total species richness was among drip diversity within a cave (a component of $\beta$-diversity), for an average of 8.67 species per cave

40

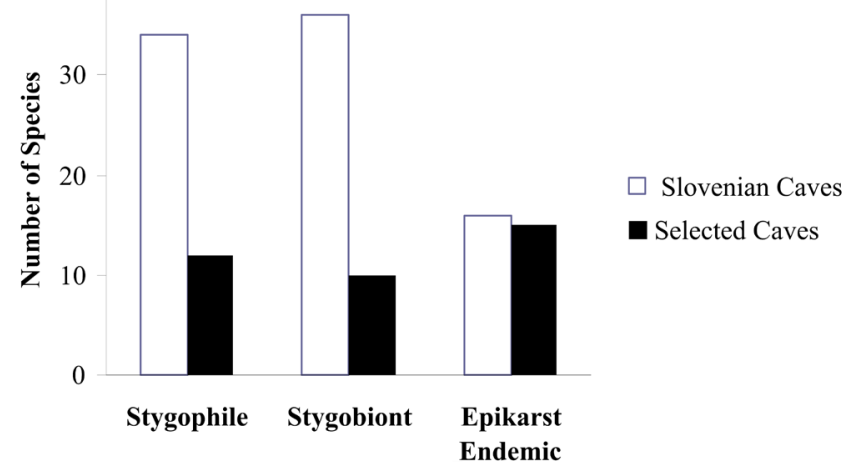

Fig. 3. Histogram of number of copepod species reported from Slovenian caves (open bars) and copepod species reported from epikarst habitats in six intensively studied caves (solid bars), according to the categories stygophile, stygobiont, and epikarst endemic. Epikarst endemics are also stygobionts, but are only listed under the epikarst endemic category. Data from Pipan (2005) and Culver et al. (2009).
Table 5. ANOVA and comparison of mean abundance of copepod collected in 35 drips by Pipan (2003).

\begin{tabular}{|l|c|c|c|c|}
\hline Sources & Sum of Squares & Mean Squares & F-ratio & $\mathbf{p}$ \\
\hline Ecological Category & 11648.73 & 5824.37 & 3.239 & 0.0516 \\
\hline Error & 61141.70 & 1796.29 & & \\
\hline Total & 72790.43 & & & \\
\hline
\end{tabular}

\begin{tabular}{|l|c|c|c|}
\hline Ecological Category & Mean & $\mathbf{n}$ & SE \\
\hline Epikarst endemic & 20.1 & 15 & 10.9 \\
\hline Other stygobionts & 52.9 & 9 & 14.1 \\
\hline Non-stygobionts & 6.6 & 13 & 11.8 \\
\hline
\end{tabular}

- 68 percent (16.33 species) of total species richness was among cave (a component of $\beta$-diversity).

Meleg et al. (2011a, 2011b) report between 3 and 6 epikarst copepod species per cave in drips and drip pools in Romania (Table 6) and a total of 11 species among their five study caves, lower numbers than those recorded for the Slovenian caves. The best estimate of total species richness was 16 species for the five Romanian caves (Meleg et al. 2011a). Based on this limited evidence, it seems likely that Slovenia and perhaps the Dinaric karst in general is a hotspot for epikarst copepod species, as it is for other subterranean aquatic groups (Sket 1999).

Not only are species numbers high in general in the Dinaric karst of Slovenia, but nearly all the species are stygobionts, in contrast to well studied caves in Romania and West Virginia, USA (Table 7). An interesting and unusual situation occurs in two nonDinaric caves in Slovenia which had very low diversity (as opposite to the general high diversity recorded for the Dinaric karst): in drips in both Huda luknja, occurring in an isolated karst area and Snežna jama na planini Arto, an ice cave in the Kamnik-Savinja Alps, only two copepod species were found in each cave, but they all were stygobionts.

\section{Ecology of epikarst fauna}

Pipan et al. (2006a) used Canonical Correspondence Analysis to search for patterns and connections between individual species and environmental parameters. In this study, it was only the samples with copepods that were used, and the emphasis was on niche differences among species. Figure 4 is a two-dimensional plot of the 12 chemical and physical parameters of epikarst drips from five Slovenian caves (Postojnska jama was excluded because species were rare and more than half of the drips had no fauna).

Table 6. Species richness of epikarst copepods for five Romanian caves. The estimated total includes observed and unobserved species, using Chao 1 estimate in EstimateS. Data from Meleg et al. (2011a).

\begin{tabular}{|l|c|}
\hline Cave & Number of Species \\
\hline Peştera Ungurului & 6 \\
\hline Peştera Vadu Crişului & 5 \\
\hline Peştera cu Apă din Valea Leşului & 5 \\
\hline Peştera Ciur Izbuc & 5 \\
\hline Peştera Doboş & 3 \\
\hline Total & 11 \\
\hline Estimated total (Chao estimate) & 15.5 \\
\hline
\end{tabular}


Table 7. Frequency of stygobiotic copepods taken from water in drips.

\begin{tabular}{|l|c|c|l|}
\hline \multicolumn{1}{|c|}{ Site } & $\begin{array}{c}\text { No. of } \\
\text { species }\end{array}$ & $\begin{array}{c}\text { Percent } \\
\text { troglobionts and } \\
\text { stygoboints }\end{array}$ & \multicolumn{1}{|c|}{ Source } \\
\hline Črna jama, Slovenia & 8 & 100 & Pipan (2005) \\
\hline Dimnice, Slovenia & 8 & 100 & Pipan (2005) \\
\hline Huda luknja, Slovenia & 2 & 100 & Pipan et al. (2008) \\
\hline $\begin{array}{l}\text { Snežna jama na planini } \\
\text { Arto, Slovenia }\end{array}$ & 2 & 10 & Papi and Pipan (2011) \\
\hline Županova jama, Slovenia & 14 & 93 & Pipan (2005) \\
\hline $\begin{array}{l}\text { Škocjanske jame, } \\
\text { Slovenia }\end{array}$ & 9 & 89 & Pipan (2005) \\
\hline Postojnska jama, Slovenia & 5 & 80 & Pipan (2005) \\
\hline Pivka jama, Slovenia & 11 & 73 & Pipan (2005) \\
\hline Peştera Doboş, Romania & 33 & 67 & Meleg et al. (2011b) \\
\hline $\begin{array}{l}\text { Peştera Ciur Izbuc, } \\
\text { Romania }\end{array}$ & 5 & 60 & Meleg et al. (2011b) \\
\hline $\begin{array}{l}\text { Cave cu Apă din Valea } \\
\text { Leşului, Romania }\end{array}$ & 4 & 50 & Meleg et al. (2011b) \\
\hline Organ Cave, W.Va., USA & 10 & 40 & Pipan et al. (2006b) \\
\hline $\begin{array}{l}\text { Peştera Ungurului, } \\
\text { Romania }\end{array}$ & 6 & 33 & Meleg et al. (2011b) \\
\hline $\begin{array}{l}\text { Peştera Vadu Crişului, } \\
\text { Romania }\end{array}$ & 5 & 20 & Meleg et al. (2011b) \\
\hline
\end{tabular}

The most important parameters which separated the different drips were $\mathrm{NO}_{3}^{-}$concentration and ceiling thickness. Each cave formed a relatively compact cluster, with Županova jama both having the largest cluster and being the most distinct. When species were superimposed on the two-dimensional plot, three clusters of species could be distinguished. One is represented by the single species Parastenocaris cf. andreji, and largely separated by low concentrations of $\mathrm{NO}_{3}^{-}$and high concentrations of $\mathrm{Na}^{+}$and $\mathrm{Cl}^{-}$, and was only found in Dimnice drips. A second cluster Moraria varica, Maraenobiotus cf. brucei, Bryocamptus dacicus, and Bryocamptus sp.- was separated by

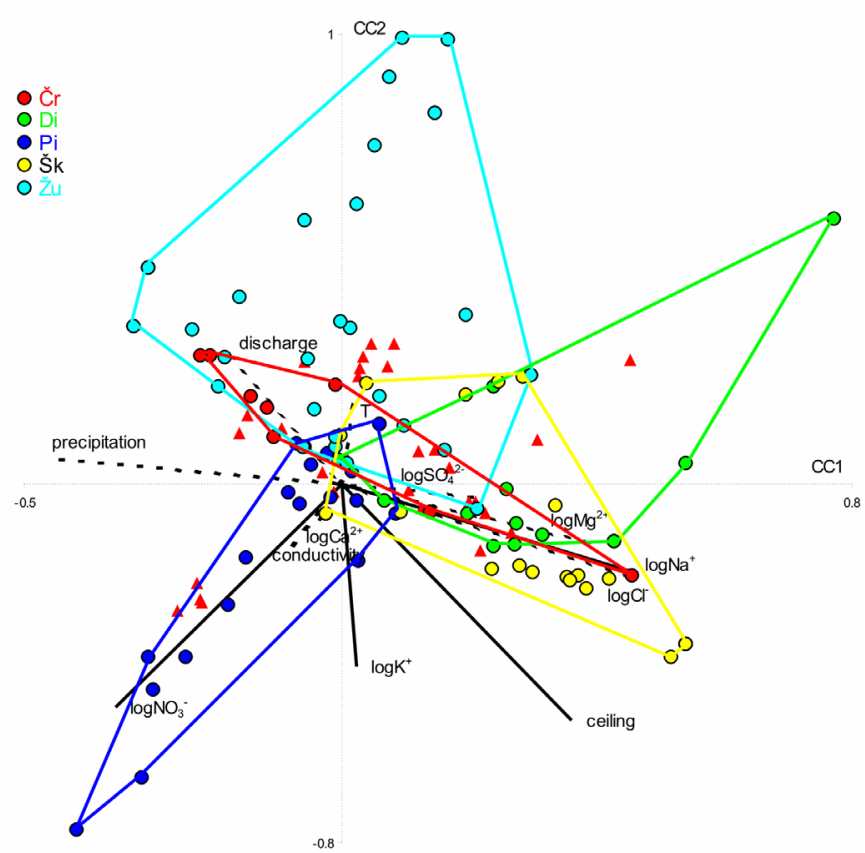

Fig. 4. Ordination diagram based on species composition and abundance data in drips in five Slovenian caves. Lines indicate the environmental variables and their orientation on the canonical axis. Triangles indicate different species and dots represent individual drips. Convex hulls enclose the drips for individual caves. From Pipan et al. (2006a). high concentrations of $\mathrm{NO}_{3}^{-}$. These species were only found in Pivka jama. A third cluster comprised all of the other species. Because the first two clusters were related not only with particular environmental conditions but also with a particular cave, it was impossible to distinguish which factor (physicalchemical or geographic separation) was important. Nevertheless, each species occupied a distinct set of sites, and even species within a cluster slightly differed in their preferential conditions. Given the highly fragmented character of epikarst and the high levels of heterogeneity of physical and chemical conditions, there are many possibilities for niche separation, both along geochemical and spatial axes. It may be this heterogeneity makes possible the high $\beta$-diversity of epikarst habitats (see above).

Meleg et al. (2011a) and Pipan et al. (2006b) report similar analyses for epikarst communities in Romania and USA, respectively. Using $\mathrm{pH}$, temperature, conductivity, and precipitation are predictor variables, Meleg et al. (2011a) produced correspondence plots for the entire epikarst community, including amphipods, isopods, ostracods, and copepods, the latter being the dominant taxa as number of species and individuals. They found that, unlike Pipan et al. (2006a), differences in conductivity were correlated with abundance of different species and that the stygobiotic taxa were usually found in water with higher conductivity. Higher conductivity implies longer residence time of the water in epikarst as the water becomes saturated with $\mathrm{CaCO}_{3}$ (Covington et al., 2012).

Moldovan et al. (2011) have made important steps in understanding why different epikarst communities are different, not just that they are different. Working in Pesstera Ciur Izbuc in Romania, they used a combination of stable isotopes, drip rates, and species composition in abundance, to understand differences between the epikarst community in two sections of the cave $300 \mathrm{~m}$ apart. They concluded that the downstream epikarst section had smaller, well connected voids that allowed for rapid transport of animals and water from the surface. The upstream section had lower secondary porosity but larger spaces (and larger animals). Finally, they also demonstrated that the surface-dwelling copepod Bryocamptus caucasicus was able to penetrate the epikarst and had a negative impact on the stygobiotic copepods, even though $B$. caucasicus likely did not maintain permanent populations in subterranean habitats.

An analysis of the relationship between geographic distance and community structure in the Organ Cave (West Virginia, U.S.A.) drip community highlights the importance of spatial heterogeneity and patchiness. The highly dissected nature of epikarst may constrain dispersal. If this is the case, then community similarity should decline rapidly with distance. Using the Jaccard index, Pipan et al. (2006b) showed a striking relationship between community differences and distance (Fig. 5). There is an increase in community dissimilarity with distances up to $100 \mathrm{~m}$, after which point there is an increase in the variability of community dissimilarity. 
Thus, drips within several hundred meters of each other tend to have similar composition and there is an expected decline in similarity with distance. This relationship between distance and dissimilarity breaks down when drips greater than $1 \mathrm{~km}$ apart were considered, and communities are substituted by new ones. The "new" communities may or may not be similar to the adjoining communities, as evidenced by the high variability of the Jaccard coefficients. Epikarst copepod communities thus form a patchwork of communities, with variation on a scale of $100 \mathrm{~m}$.

\section{Morphological characteristics}

Brancelj (2007, 2009) gave a number of intriguing suggestions about uniquely convergent features of epikarst copepods. Working with the genera Morariopsis and Paramoriopsis, he pointed out that animals living in the epikarst must have some morphological adaptations to prevent or minimize their transport downward. Combined with what he considers a low supply of organic carbon, he proposes that the following convergent features are present in specialized epikarstic copepods to avoid being displaced by water flow

- Reduction in endopodal segmentation to two or one;

- Reduction in number of spines and setae on the terminal segments of both endopods and exopods;

- Reduction in number of spines and setae on the caudal rami to one terminal seta;

- Tips of the terminal setae of the caudal rami are far apart;

- Short and robust setae on the endopodal lobe of fifth leg (P5) as well as very strong spinules at the base of the caudal rami.

Brancelj (2009) demonstrated that the genus Elaphoidella shows similar convergent features, especially the last two. He also proposed that there is convergent reduction on length of the antennules and that robust setae are probably an adaptation for moving through small spaces in fractured rock as well as a protection against washout.

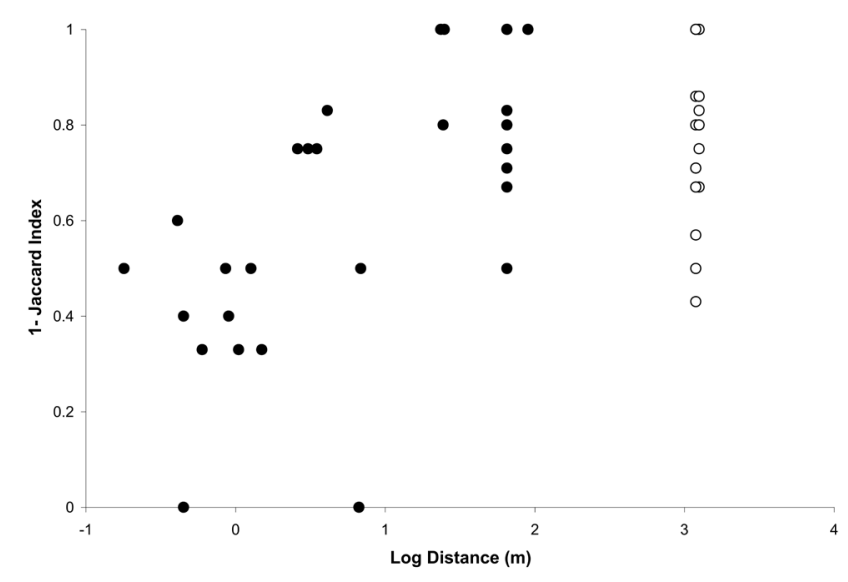

Fig. 5. Semilog plot of geographic distance (in $\mathrm{m}$ ) against (1-J), where $\mathrm{J}$ 's are Jaccard indices. Closed circles are pairs of drips on the same side of the syncline that is the major structure determinant of cave passage position; open circles are on opposite sides of the syncline.

\section{Faunal differences between drips and drip pools}

Most data on epikarst fauna comes from collections of individuals from drip pools. Drip pools are not necessarily passive collectors of the epikarst fauna in drips, and Pipan et al. (2010) specifically addressed the question of whether the fauna of drip pools reflected the drip community. Overall, the frequency of stygobionts was 1.5 times higher in drips than in pools, and the frequency of stygobionts that were epikarst specialists was three times higher in drips compared with pools. The frequency of immature individuals, suggestive of reproduction at the site, was also higher in drips than in pools, with the exception of one artificially enlarged pool in Škocjanske jame. Pipan et al. (2010) suggest that there is increased juvenile mortality in pools and reduced reproduction, indicating that pools are not "source populations", i.e., populations that are selfsustaining in the absence of migrants (Pulliam, 1988).

\section{CRITIQUES AND CHALLENGES}

Several criticisms and challenges have been posed to the reality and utility of the concept of epikarst. Two of them are hydrogeological, those of Šušteršič (1999) and Kresic (2013), and one is biological, that of Sket et al. (2004).

Based on his geological studies of the Dinaric karst where there is both rapid uplift and rapid denudation of karst, Šušteršič (1999) sees epikarst as a zone of destruction of karst, which he calls speleothanatic space. There is little doubt that in circumstances of both rapid uplift and erosion, caves become unroofed and a destruction zone can be identified. Even in this case, epikarst can still have major hydrological function for water storage, a point that Šušteršič did not address. Šušteršič's work does point out the transitory nature of epikarst, more so than the underlying caves.

Kresic (2013) offers two objections to the widespread use of the term epikarst. First, he argues that epikarst is absent in many places. This is an empirical question, and its presence or absence in flank margin caves and hypogenic caves, for example, is unknown (Jones, 2013). Curiously, Kresic (2013) uses the presence of vertical shafts and sinkholes as evidence for epikarst, but they are not an integral part of epikarst, and Bakalowicz (2004) even argues that they are not even part of epikarst, since it represents rapid transmission routes through upper karst layers. Secondly, Kresic (2013) quite correctly points out that epikarst is not a usable aquifer by humans, but that speaks to its size, not its presence.

Sket et al. (2004) hold that there is no distinct epikarst fauna, and consider it part of the upper vadose fauna, which is also called the percolation zone. The method of collecting epikarst water necessarily means that it includes water in both epikarst and the percolation zone below it. However, it is likely that most of the animals are in the epikarst rather than the percolation zone, for two reasons, one hydrological and the other based on species occurrence patterns. As the pioneering work of the hydrogeologists Bakalowicz, Mangin, and Williams demonstrates, most of the water is stored in the epikarst 
zone. This volumetric relationship suggests most individuals are in the epikarst rather than other areas, especially since the upper vadose zone is a region of vertically moving water. In addition, Pipan et al. (2006a) found that the abundance of all stygobiotic copepod species except Elaphoidella cvetkae was negatively correlated with ceiling thickness (see Fig. 4). If the upper vadose zone were the major habitat, then most species should have a pattern like that of $E$. cvetkae. If the upper vadose zone were the major habitat, it is difficult to explain the high diversity in Velika Pasica and other caves with thin ceilings and essentially no upper vadose zone. Because all sampling is indirect, it cannot be known with certainty what the distribution of species in the epikarst and upper vadose is. While it is highly likely that, for the reasons given above, the major habitat is epikarst, many species may well occur in other part of the upper vadose zone. Thus, strictly speaking, it is likely that most epikarst species occur, albeit in much smaller numbers, in the upper vadose, percolation zone. Nevertheless, epikarst endemic is a very useful phrase to describe these species, just as riparian species may occasionally occur away from stream margins.

\section{DIRECTIONS FOR FUTURE RESEARCH}

So much is not known about epikarst that it is difficult to prioritize research needs. However, the following directions seem to be most promising. First, part of the difficulty of studying epikarst is that all sampling is indirect, and we can only infer habitat structure and subdivision. Any method of direct observation or direct sampling, perhaps through pumping, should yield important results. Second, understanding the reasons for the differences in species composition and richness of epikarst communities, especially in small scale, is an obvious next step forward. The promising start of Moldovan et al. (2011), one that combines hydrological, biological, and stable isotope data, should be expanded. Third, none of the epikarst fauna has been put in a phylogenetic context. Are these species basal to species in deeper subterranean habitats, or do they tend to form distinct clades? Phylogeographic studies would also provide some initial estimates of the age of the epikarst fauna. Fourth, the suggestion of Pipan and Culver (2007b) that copepods could be used as epikarst water tracers should be pursued.

\section{ACKNOWLEDGEMENTS}

This paper was modified and adapted from a chapter on "Epikarst" for a book by Culver and Pipan, Shallow Subterranean Habitats. Ecology, Evolution, and Conservation, to be published by Oxford University Press. Several anonymous reviewers offered very useful comments.

\section{REFERENCES}

Bakalowicz M., 2004 - The epikarst, the skin of karst. In: Jones WK, Culver DC \& Herman JS. (Eds.) - Epikarst. Proceedings of the symposium held October 1 through 4, 2003 Shepherdstown, West Virginia, USA. Charles Town, West Virginia, U.S.A.: Karst Waters Institute: 16-22.
Bakalowicz M., 2012 - Epikarst. In: White WB \& Culver DC. (Eds.) - Encyclopedia of caves, second edition. Amsterdam, The Netherlands: Elsevier Press: 284-288. http://dx.doi.org/10.1016/B978-0-12-383832-2.00038-4

Ban R., Pan G., Zhu J., Cai B. \& Tan M., 2008 - Temporal and spatial variations in the discharge and dissolved organic carbon of drip waters in Beijing Shihua Cave, China. Hydrological Processes, 22: 3749-3758. http://dx.doi.org/10.1002/hyp.6979

Bottrell S.H. \& Atkinson T.C., 1992 - Tracer study and storage in the unsaturated zone of a karstic limestone aquifer. In: Hotzl H. \& Werner H. (Eds.) - Tracer hydrology. Rotterdam, The Netherlands: Balkema: 207-211.

Brancelj A., 2002 - Microdistribution and high diversity of Copepoda (Crustacea) in a small cave in central Slovenia. Hydrobiologia, 477: 59-72.

http://dx.doi.org/10.1023/A:1021043014879

Brancelj A., 2007 - The epikarst habitat in Slovenia and the description of a new species. Journal of Natural History, 40: 403-413.

http://dx.doi.org/10.1080/00222930600646608

Brancelj A., 2009 - Fauna of an unsaturated karstic zone in central Slovenia: two new species of Harpacticoidea (Crustacea: Copepoda), Elaphoidella millennii n.sp. and E. tarmani n.sp., their ecology and morphological adaptations. Hydrobiologia, 621: 85-104. http://dx.doi.org/10.1007/s10750-008-9634-3

Camacho A.I., Valdecasas A.G., Rodríguez, J., Cuezva, S., Lario, J. \& Sánchez-Moral S., 2006 - Habitat constraints in epikarstic waters of an Iberian Peninsula cave system. International Journal of Limnology, 42: 127-140. http://dx.doi.org/10.1051/limn/2006009

Covington M.D., Luhmann A.J., Wicks C.M. \&Saar M., 2012 - Process length scales and longitudinal damping in karst conduits. Journal of Geophysical Research Earth Surface, 117.

http://dx.doi.org/10.1029/2011JF002212

Culver D.C. \& Pipan T., 2011 - Redefining the extent of the aquatic subterranean biotope-shallow subterranean habitats. Ecohydrology, 4: 721-730.

http://dx.doi.org/10.1002/eco.243

Culver D.C., Pipan T. \& Schneider K., 2009 - Vicariance, dispersal, and scale in the aquatic subterranean fauna of karst regions. Freshwater Biology, 54: 918-929. http://dx.doi.org/10.1111/j.1365-2427.2007.01856.x

Delay B., 1968 - Donnees sur le peuplement de la zone de percolation temporaire. Annales de Spéologie, 23: 705-733.

Ford D. \& Williams P., 2007 - Karst hydrogeology and geomorphology. John Wiley \& Sons, New York, 576 p. http://dx.doi.org/10.1002/9781118684986

Gibert J., 1986 - Ecologie d'un systeme karstique jurassien. Hydrogéologie, dérive animale, transits de matières, dynamique de la population de Niphargus (Crustacé Amphipode). Mémoires de Biospéologie, 13: 1-379.

Holsinger J.R., 1971 - Observations on a population of the cavernicolous amphipod crustacean Crangonyx antennatus Packard. Virginia Journal of Science, 22: 97.

Jones W.K., 2013 - Physical structure of the epikarst. Acta Carsologica, 42.

Jones W.K., Culver D.C. \& Herman J.S., (Eds.) 2004 - Epikarst. Proceedings of the symposium held October 1 through 4, 2003 Sheperdstown, West Virginia, USA. Karst Waters Institute, Charles Town, West Virginia, U.S.A., 160 p.

Kogovšek J., 2010 - Characteristics of percolation through the karst vadose zone. ZRC Publishing, Ljubljana, Slovenia: $168 \mathrm{p}$.

Kogovšek J. \& Urbanc J., 2007 - Ocena dinamike premikajoče vode skozi vadozno cono Postojnske jame na osnovi izotopskih značilnosti. Geologija, 56: 477-486. http://dx.doi.org/10.5474/geologija.2007.033 
Kresic N., 2013 - Water in karst. McGraw-Hill, New York, 736 p.

Malard F., Boutin C., Camacho A.I., Ferreira D., Michel G., Sket B. \& Stoch F., 2009 - Diversity patterns of stygobiotic crustaceans across multiple spatial scales in Europe. Freshwater Biology, 54: 756-776.

http://dx.doi.org/10.1111/j.1365-2427.2009.02180.x

Mangin A. 1973 - Sur la dynamique des transferts en aquifer karstique. Proceedings of the Sixth International Congress of Speleology, Olomouc. 4: 157-162.

McKnight D. M., Boyer E. W., Westerhoff P. K., Doran P.T., Kulbe, T. \& Andersen, D. T., 2001 - Spectrofluorometric characterization of dissolved organic matter for indication of precursor organic material and aromaticity. Limnology and Oceanography 46: 38-38.

http://dx.doi.org/10.4319/10.2001.46.1.0038

Meleg I.N., Fiers F. \& Moldovan O.T., 2011a - Assessing copepod (Crustacea: Copepoda) species richness at different spatial scales in northwestern Romanian caves. Subterranean Biology, 9: 103-112.

http://dx.doi.org/10.3897/subtbiol.9.2513

Meleg I.N., Moldovan O.T., Iepure S., Fiers F. \& Brad T., 2011b - Diversity patterns of fauna in dripping water of caves from Transylvania. Annales de Limnologie/ International Journal of Limnology, 47: 185-197. http://dx.doi.org/10.1051/limn/2011014

Moldovan O.T., Meleg I.N. \& Perşiou A., 2011 Habitat fragmentation and its effects on groundwater populations. Ecohydrology, 5: 445-452.

http://dx.doi.org/10.1002/eco.237

Papi F. \& Pipan T., 2011 - Ecological studies of an epikarst community in Snežna jama na planini Arto - an ice cave in north central Slovenia. Acta Carsologica, 40: 505-513.

Petkovski T.K., 1959 - Fauna Copepoda pećine "Dona Duka" kod rašča-Skopje. Fragmenta Balcanica, 2: 107-123.

Pipan T., 2003 - Ekologija ceponožnih rakov (Crustacea: Copepoda) $v$ prenikajoči vodi izbranih kraških jam. Ph.D. Dissertation, University of Ljubljana, Ljubljana, Slovenia: $130 \mathrm{p}$.

Pipan T., 2005 - Epikarst - a promising habitat. Založba ZRC, Ljubljana, Slovenia: $101 \mathrm{p}$.

Pipan T., Blejec A. \& Brancelj A., 2006a - Multivariate analysis of copepod assemblages in epikarstic waters of some Slovenian caves. Hydrobiologia, 559: 213-223. http://dx.doi.org/10.1007/s10750-005-0920-z

Pipan T. \& Brancelj A., 2001 - Ratio of copepods (Crustacea: Copepoda) in fauna of percolation water in six karst caves in Slovenia. Acta Carsologica, 30: 257-266.

Pipan T., Christman, M.C. \& Culver D.C., 2006b Dynamics of epikarst communities: microgeographic pattern and environmental determinants of epikarst copepods in Organ Cave, West Virginia. American Midland Naturalist, 156: 75-87. http://dx.doi.org/10.1674/00030031(2006)156[75:DOECMP]2.0.CO;2

Pipan T. \& Culver D.C., 2005 - Estimating biodiversity in the epikarstic zone of a West Virginia cave. Journal of Cave and Karst Studies, 67: 103-109.

Pipan T. \& Culver D.C., 2007a - Regional species richness in an obligate subterranean dwelling fauna-epikarst copepods. Journal of Biogeography, 34: 854-861. http://dx.doi.org/10.1111/j.1365-2699.2006.01667.x
Pipan T. \& Culver D.C., 2007b - Copepod distribution as an indicator of epikarst system connectivity. Hydrogeology Journal, 15: 817-822.

http://dx.doi.org/10.1007/s10040-006-0114-4

Pipan T., Holt N. \& Culver D.C., 2010 - How to protect a diverse, poorly known, inaccessible fauna: identification of source and sink habitats in the epikarst. Aquatic Conservation: Marine and Freshwater Ecosystems, 20: 748-755. http://dx.doi.org/10.1002/aqc.1148

Pipan T., Navodnik V., Janžekovič F. \& Novak T., 2008 - First studies on the fauna of percolation water in Huda Luknja, a cave in the isolated karst in northeast Slovenia. Acta Carsologica, 37: 141-151.

Pulliam H.R., 1988 - Sources, sinks, and population regulation. American Scientist, 132: 652-661.

Racoviță E.G. 1907 - Essai sur les problèmes biospéologiques. Archives de Zoologie Expérimentale et Générale, 6: 371-488.

Rouch R., 1968 - Contribution a la connaissance de Harpacticides hypogés (Crustacés - Copépodes). Annales de Spéléologie, 23: 9-167.

Simon K.S. \& Benfield E.F., 2002 - Ammonium retention and whole-stream metabolism in cave streams. Hydrobiologia, 482: 31-39.

http://dx.doi.org/10.1023/A:1021257822591

Simon K.S., Benfield E.F. \& Macko S.A., 2003 - Food web structure and the role of epilithic films in cave streams. Ecology, 84: 2395-2406. http://dx.doi.org/10.1890/02-334

Simon K.S., Pipan T. \& Culver D.C., 2007 - A conceptual model of the flow and distribution of organic carbon in caves. Journal of Cave and Karst Studies, 69: 279-284.

Simon K.S., Pipan T., Ohno T. \& Culver D.C., 2010 - Spatial and temporal patterns in abundance and character of dissolved organic matter in two karst aquifers. Fundamental and Applied Limnology 177: 81-92. http://dx.doi.org/10.1127/1863-9135/2010/0177-0081

Sket B., 1999 - The nature of biodiversity in subterranean waters and how it is endangered. Biodiversity and Conservation, 8: 1319-1338. http://dx.doi.org/10.1023/A:1008916601121

Sket B., Trontelj P. \& Žagar C., 2004 - Speleobiological characterization of the epikarst and its hydrological neighborhood: its role in dispersion of biota, its ecology and vulnerability. In: Jones W.K, Culver D.C. \& Herman J.S. (Eds.) - Epikarst. Proceedings of the symposium held October 1 through 4, 2003 Shepherdstown, West Virginia, USA. Charles Town, West Virginia, U.S.A.: Karst Waters Institute: 104-113.

Šušteršič F., 1999 - Vertical zonation of the speleogenetic space. Acta Carsologica, 28: 187-201.

Weishaar J.L., Aiken G.R., Bergamaschi B.A., Fram M.S., Fujii R. \& Mopper, K., 2003 - Evaluation of specific ultraviolet absorbance as an indicator of the chemical composition and reactivity of dissolved organic carbon. Environmental Science and Technology, 37: 4702-4708. http://dx.doi.org/10.1021/es030360x

Williams P.W., 1983 - The role of subcutaneous zone in karst hydrology. Journal of Hydrology, 61: 45-67. http://dx.doi.org/10.1016/0022-1694(83)90234-2

Williams P.W., 2008 - The role of the epikarst in karst and cave hydrogeology: a review. International Journal of Speleology, 37: 1-10. http://dx.doi.org/10.5038/1827-806X.37.1.1 